\title{
Phenological metrics of the grassland vegetation of Rio Grande do Sul, Brazil
}

\author{
Andreise Moreira ${ }^{1}$, Denise C. Fontana ${ }^{1}$, Tatiana M. Kuplich ${ }^{2} \&$ Laurindo A. Guasselli $^{1}$ \\ ${ }^{1}$ Universidade Federal do Rio Grande do Sul. Porto Alegre, RS, Brasil. E-mail: andreisem@gmail.com (Corresponding author) - ORCID: 0000-0001- \\ 6932-2794; dfontana@ufrgs.br - ORCID: 0000-0002-2635-6086; laurindo.guasselli@ufrgs.br - ORCID: 0000-0001-8300-846X \\ ${ }^{2}$ Instituto Nacional de Pesquisas Espaciais/Centro Regional Sul de Pesquisas Espaciais. Santa Maria, RS, Brasil. E-mail: tatiana.kuplich@inpe.br - ORCID: \\ 0000-0003-0657-4024
}

\begin{abstract}
Considering that plant phenology studies allow establishing relationships between phenological patterns of vegetation and changes caused by climate variability, the aim of this study was to obtain phenological metrics for the predominant grassland typologies in Rio Grande do Sul State, Brazil (latitudes $27^{\circ} 05^{\prime}$ and $33^{\circ} 45^{\prime} \mathrm{S}$ and longitudes $49^{\circ} 43^{\prime}$ and $57^{\circ} 39^{\prime} \mathrm{W}$ ) and to evaluate the spatial-temporal distribution pattern of these metrics under the influence of the subtropical climate variability. The phenological metrics were obtained based on the time series of the EVI (Enhanced Vegetation Index), of the sensor MODIS (Moderate Resolution Imaging Spectroradiometer), for the period from 2001 to 2014, through the Timesat program. Eleven phenological metrics were extracted, identifying the presence of two spatial distribution patterns of grass-dominated typologies in the Rio Grande do Sul state, Brazil, one located in the south-central region and the other located in the northeast, along the coast and in the western portion of the state. In addition, it was also observed that the phenological pattern of the grassland vegetation of the state of Rio Grande do Sul, Brazil, is controlled by the seasonality of vegetation, mainly associated with the variations in air temperature.
\end{abstract}

Key words: EVI, Timesat, time series

\section{Métricas fenológicas da vegetação de pastagens do Rio Grande do Sul, Brasil}

RESUMO: Considerando que o estudo da fenologia vegetal permite estabelecer relações entre o padrão fenológico da vegetação e as alterações causadas pela variabilidade climática, o objetivo deste trabalho foi obter métricas fenológicas para as tipologias de vegetação de pastagens predominantes no Rio Grande do Sul (latitudes $27^{\circ} 05^{\prime}$ e $33^{\circ} 45^{\prime}$ S e longitudes $49^{\circ} 43^{\prime}$ e $57^{\circ} 39^{\prime} \mathrm{W}$ ) e avaliar o padrão de distribuição espaçotemporal destas métricas sob influência da variabilidade climática subtropical. A obtenção de 11 métricas fenológicas foi realizada com base na série temporal do EVI (Enhanced Vegetation Index) do sensor MODIS (Moderate Resolution Imaging Spectroradiometer), para o período de 2001 a 2014, por meio do programa Timesat. Identificou-se a presença de dois grupos espaciais de tipologias campestres no Estado do Rio Grande do Sul, um na região centro-sul e outro na região nordeste, ao longo do litoral e no oeste do Estado. Observou-se ainda que o padrão fenológico da vegetação de pastagens do Rio Grande do Sul é controlado pela sazonalidade da vegetação associada, principalmente, à variação da temperatura do ar.

Palavras-chave: EVI, Timesat, série temporal 


\section{INTRODUCTION}

Phenology is a seasonal phenomenon determined by the relationship between plants and climate and by biotic and abiotic factors that influence the pace of vegetation growth and development (Lieth, 1974). Phenological changes associated with climatic variability act as an indicator of impacts of climate variations (Soudani et al., 2012), with significant effect on ecosystem productivity.

The evaluation of vegetation phenology patterns and detection of alterations associated with either natural or anthropic disturbances, performed using satellite images (Tiedemann, 2011), provides data that are temporally continuous and at different scales, from local to global (Zhang et al., 2006). The use of vegetation indices (EVI - Enhanced Vegetation Index and NDVI - Normalized Difference Vegetation Index) and their relationship with climate variability and large-scale events such as El Niño and La Niña (Zhang et al., 2006; Paruelo, 2008; Hermance et al., 2015) stand out, but with the definition only of the phases of start and end of growth and vegetative peak.

This is also observed in the studies addressing the grassland vegetation in Southern Brazil, especially the Pampa biome (Wagner et al., 2013; Scottá \& Fonseca, 2015; Junges et al., 2016). Most of the studies conducted do not use a methodology capable of covering different spatial scales and that allow spatial-temporal analyses in a continuous manner and of different phenological metrics, providing information about the vegetation pattern in response to changes occurring on the terrestrial surface, by anthropic influence, natural phenological influences or climatic variability.

Thus, this study aimed to obtain phenological metrics for the predominant grassland typologies in Rio Grande do Sul state, Brazil, and evaluate the spatial-temporal distribution pattern of these metrics under the influence of the subtropical climatic variability.

\section{Material ANd Methods}

The study area covered 10 predominant grassland typologies in the state of Rio Grande do Sul, Brazil (270 05' and $33^{\circ} 45^{\prime} \mathrm{S}$ latitudes and $49^{\circ} 43^{\prime}$ and $57^{\circ} 39^{\prime} \mathrm{W}$ longitudes). The typologies were defined based on the Map of Ecological Systems of the Uruguayan Savannas (Hasenack et al., 2010) and on the physiognomic description elaborated by Boldrini \& Longhi-Wagner (2011) (Figure 1).

Two time series of estimated data were obtained: one of rainfall, from TRMM (Tropical Rainfall Measuring Mission), and the other of air temperature, from ERA Interim, both for the period from 2001 to 2014. Data collection corresponded to the central geographic coordinate obtained in 20 sampling polygons for each grassland typology.

TRMM rainfall values were estimated using data of the 3B43 (TRMM and Other Sources Monthly rainfall) algorithm, which provides estimates of hourly rainfall $\left(\mathrm{mm} \mathrm{h}^{-1}\right)$, daily rainfall $\left(\mathrm{mm} \mathrm{d}^{-1}\right)$ and monthly rainfall $\left(\mathrm{mm} \mathrm{month}^{-1}\right)$ in a spatial resolution grid of $0.25^{\circ} \times 0.25^{\circ}$. The values of daily rainfall were accumulated every 16 days, obtained from the

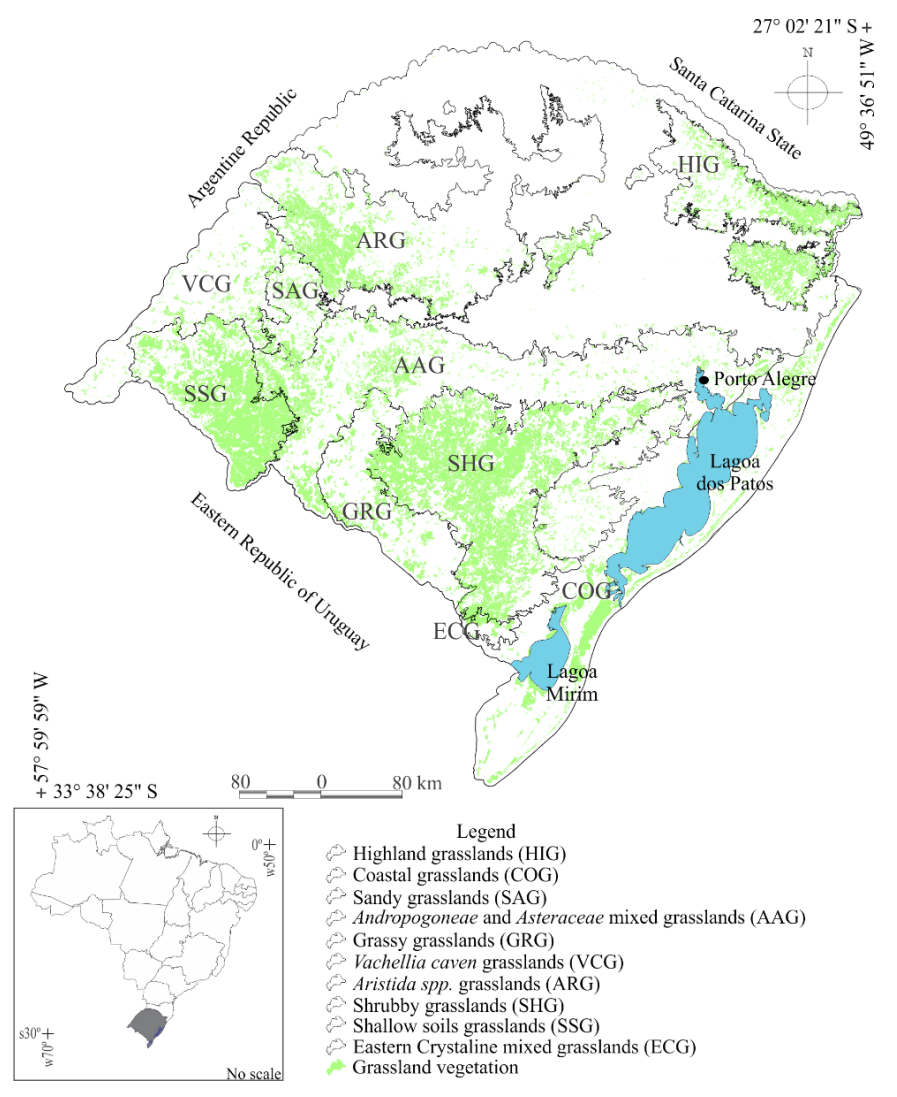

Source: Adapted from Hasenack et al. (2010) and Weber et al. (2009)

Figure 1. Grassland mask and location of grassland typologies

average value of the 20 sampling polygons for each of the 10 grassland typologies of Rio Grande do Sul state, Brazil. At the end, the value accumulated every 16 days was used to obtain the averages for each climate season of the year.

Air temperature values correspond to the ERA Interim, a global atmospheric reanalysis database produced and made available by the ECMWF (European Centre for Medium-Range Weather Forecasts) for the period from 1979 to the present time (Berrisford et al., 2011; Balsamo et al., 2015). Data are obtained at $2 \mathrm{~m}$ height from the surface in a spatial resolution grid of $0.25^{\circ} \times 0.25^{\circ}$. Air temperature values followed the same processing of rainfall values, but the averages of daily values were obtained organized in 16-day cycles. The data was organized in 16-day cycles in order to make the meteorological data series compatible with the EVI vegetation index data set made available by the MODIS sensor.

The phenological metrics of the grassland typologies were extracted using the Timesat program created by Jönsson \& Eklundh $(2002,2004)$ for analysis of satellite data time series, allowing the extraction of seasonal information of the vegetation (Gao et al., 2008; Prabakaran et al., 2013).

The time series between January 2001 and December 2014 was considered, in a total of 322 images of EVI/MODIS and the images were pre-processed, converting the files from .tif to .bin (binary files) and the radiometric resolution from 8 to 16 bits through the Interactive Data language (IDL) programming language.

Pixel reliability data were also used for weighing in the time series filtration. Better-quality pixels received higher weights (1) and lower-quality pixels received lower weights (0.5) or zero (0), according to Jönsson \& Eklundh (2004). 
The images were also processed by the Savitsky-Golay filter to smooth the time series. This filter is based on the definition of the source of the signal, width and central point of the interval. From this, the central point is removed from the set of points of the interval and the least squares method is used to fit a variable-order polynomial to the remaining points. This polynomial is used to estimate the value of the removed point and, subsequently, shift the interval to the next point of the original signal. After obtaining the value of the first point, the previous process is repeated (Cerqueira et al., 2000).

For the analyzed data series, eleven phenological metrics were extracted in the Timesat program, which are presented in Table 1. Phenological metrics were generated for each year and, at the end, the average values of each phenological metric was obtained for the period between 2001 and 2014 .

In order to highlight the areas of grassland vegetation, after obtaining the phenological metrics, a grassland mask (Figure 1), elaborated by Weber et al. (2009), was applied to the average image. The mask includes the following grasslands: dry, humid, with rocky outcrops and coastal grasslands.

\section{Results And Discussion}

The pattern of growth and development of the grassland vegetation in Rio Grande do Sul state, Brazil, followed a variation pattern similar to that of air temperature. During spring and summer, the increment in air temperature is associated with the highest values of EVI $(\sim 0.42)$. Conversely, the reduction in air temperature in autumn and winter is associated with the lowest values of EVI ( 0.37) (Figure 2A). This pattern characterizes the phenology of the grassland vegetation in the entire Rio Grande do Sul state, Brazil, (Scottá \& Fonseca, 2015; Junges et al., 2016).

For the rainfall distribution pattern (Figure 2B), there was a certain regularity between the four seasons of the year. There are differences between the regions, and the highest values were observed on Aristida spp. grasslands (ARG) and highland grasslands (HIG), with a reduction to the west and south, where the other typologies predominate, similar to the results presented by Wagner et al. (2013).

The relationship between EVI and air temperature was higher than the relationship between EVI and rainfall. For all typologies, there were significant correlation coefficients between EVI and air temperature in the autumn, with a reduction during the winter for the HIG and ARG typologies and in the spring for coastal grasslands (COG), Vachellia caven grasslands (VCG), shallow soils grasslands (SSG) and eastern crystaline mixed grasslands (ECG). Lower correlation values were obtained in the summer for most typologies (Table 2).

Although water availability is fundamental for vegetation development, being one of its main regulators, and considering that the increase of air temperature, especially in the summer, characterizes greater evaporative demand of the atmosphere, the present study found no direct correlation between rainfall and EVI for most grassland typologies and seasons of the year (Table 2). Wagner et al. (2013), evaluating the relationship between variations in the deviations from the average of EVI and deviations of rainfall from meteorological stations in areas of grassland vegetation in Rio Grande do Sul state, Brazil, and Uruguay, obtained variable values of correlation coefficient (r) along the year but, in general, the values showed low correlation. It was observed that the increase in the values of accumulated rainfall in the spring and summer coincided with the increase in EVI values.

The analyzed series used average values for the entire period, minimizing the capacity for correlating EVI with rainfall. Future studies considering distinct time scales, anomalous periods or caused by the influence of large-scale events such as El Niño and La Niña, which alter the rainfall rates in the state (Berlato \& Fontana, 2003), may be conducted in order to obtain information on the dynamics of the response of the grassland vegetation and climatic variability in RS.

The results obtained from the average pattern of phenological metrics (2001 to 2014), (Figure 3; Table 3), allowed identifying that, despite the similar annual pattern, there are differences in the phenology of the grassland vegetation between the predominant typologies in Rio Grande do Sul state, Brazil.

The increment of air temperature in the beginning of spring determined the start of vegetation growth (regrowth), a period with predominance of hibernating grasses, with $\mathrm{C}_{3}$ photosynthetic metabolism (Boldrini et al., 2015). The dates of start of the vegetative cycle ranged between September and October, with variation between the typologies (Figure 3A).

For the typologies sandy grasslands (SAG), Andropogonean and Asteraceae mixed grasslands (AAG), shrubby grasslands (SHG), ECG, COG, VCG and SSG, located in the south-central region, the start of the growth cycle occurs one month earlier (September) compared to the typologies HIG, ARG and grassy grasslands (GRG), present in the Northeast region, coastline and far west of the state, respectively (Table 3). In this period,

Table 1. Description of phenological metrics extracted in the Timesat program

\begin{tabular}{|c|c|c|c|}
\hline Item & Phenological metrics & Unit & Description \\
\hline 1 & Start of vegetative cycle & Period* & Start of season \\
\hline 2 & End of vegetative cycle & Period & End of season \\
\hline 3 & Date of maximum photo synthetic activity & Period & Period of maximum photo synthetic activity \\
\hline 4 & Duration of vegetative cycle & Days & Interval between start and end of season \\
\hline 5 & Minimum photosynthetic activity (Base level) & Enhanced Vegetation Index** & Minimum photosynthetic activity \\
\hline 6 & Maximum photosynthetic activity (Maximum value) & Enhanced Vegetation Index & Maximum photosynthetic activity \\
\hline 7 & Seasonal amplitude & Enhanced Vegetation Index & Seasonal variation of photosynthetic activity \\
\hline 8 & Growth rate (Left derivative) & Day/ Enhanced Vegetation Index & Vegetation growth variation rate \\
\hline 9 & Senescence rate (Right derivative) & Day/ Enhanced Vegetation Index & Vegetation senescence variation rate \\
\hline 10 & Total productivity (Upper integral) & Day/ Enhanced Vegetation index & Vegetation total productivity \\
\hline 11 & Seasonal productivity (Lower integral) & Day/ Enhanced Vegetation index & Seasonally active vegetation \\
\hline
\end{tabular}

Source: Adapted from Jönsson \& Eklundh (2004); Tan et al. (2011); Teles et al. (2015); ${ }^{\star}$ Period - Corresponds to the month of the year; ${ }^{\star *}$ Enhanced Vegetation Index - EVI value varying from 0 to 1 


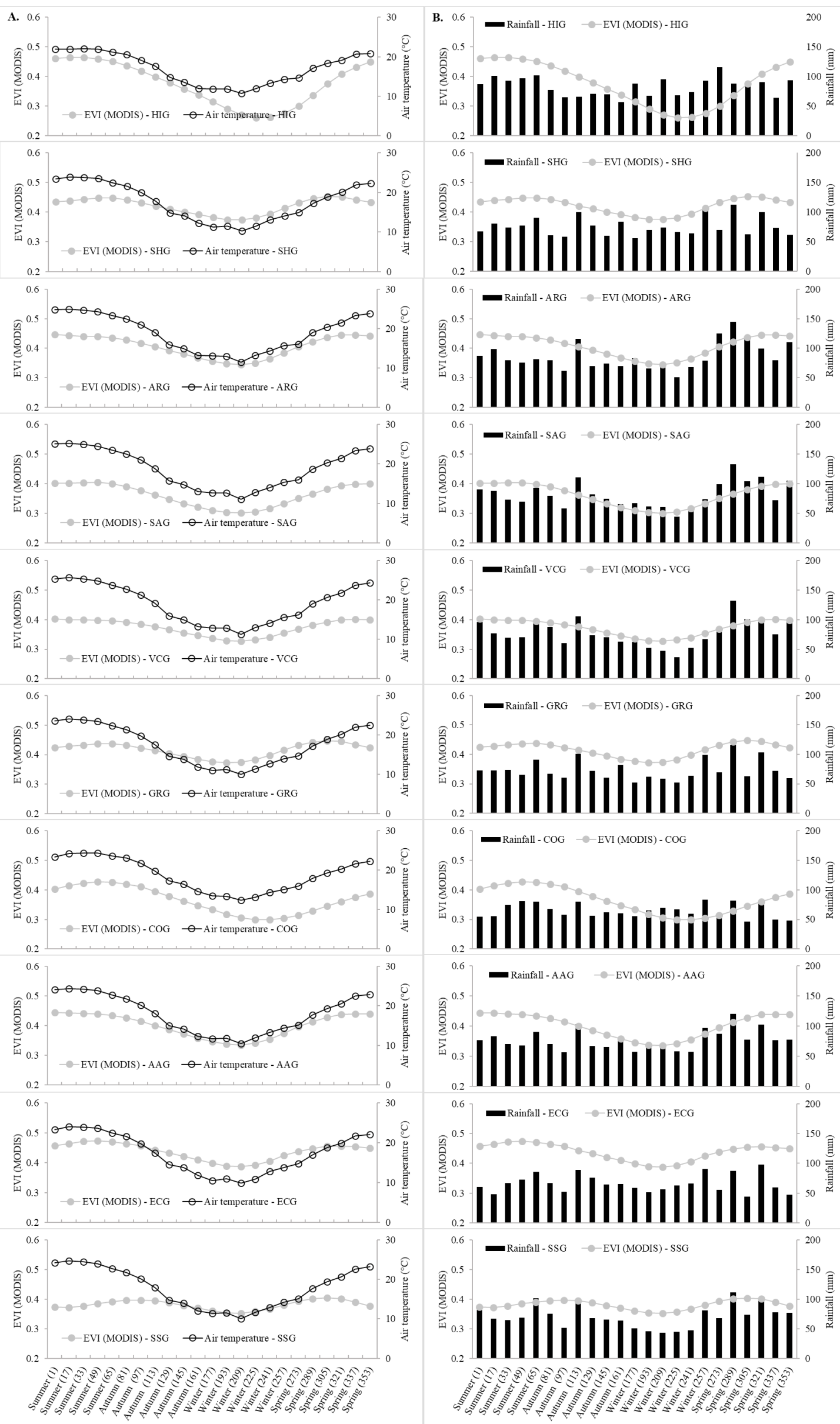

See Figure 1 to identify the grassland typologies

Figure 2. Average values of the temporal distribution of Enhanced Vegetation Index (EVI) and air temperature (A) and EVI and rainfall (B) for the 2001-2014 time series and for the 10 predominant grassland typologies in Rio Grande do Sul state, Brazil 
Table 2. Values of correlation coefficients between Enhanced Vegetation Index (EVI) and air temperature and between EVI and rainfall for 10 grassland typologies of RS. Gray Underline indicates significant correlation by Student's t-test at $\mathrm{p} \leq 0.05$

\begin{tabular}{|c|c|c|c|c|c|c|c|c|c|c|}
\hline \multirow{2}{*}{ Season } & \multicolumn{10}{|c|}{ Grassland typologies } \\
\hline & HIG & COG & SAG & $\overline{A A G}$ & GRG & VCG & $\overline{A R G}$ & SHG & SSG & ECG \\
\hline \multicolumn{11}{|c|}{ EVI and Temperature } \\
\hline Spring & $\underline{0.98}$ & 0.09 & $\underline{0.93}$ & $\underline{0.98}$ & $\underline{0.95}$ & -0.29 & $\underline{0.99}$ & $\underline{0.96}$ & 0.71 & -0.49 \\
\hline Summer & $\underline{\underline{0.95}}$ & -0.52 & $\underline{0.87}$ & $\overline{0.59}$ & $\overline{0.71}$ & -0.61 & $\overline{0.60}$ & $\underline{\underline{0.89}}$ & 0.00 & $\underline{-0.92}$ \\
\hline Autumn & $\overline{0.99}$ & $\underline{0.99}$ & $\overline{0.99}$ & $\underline{0.99}$ & $\underline{0.98}$ & $\underline{0.99}$ & $\underline{0.99}$ & $\overline{0.99}$ & $\underline{0.99}$ & $\overline{0.91}$ \\
\hline Winter & -0.19 & $\underline{0.94}$ & $\underline{0.94}$ & $\underline{0.93}$ & $\underline{0.93}$ & $\underline{0.94}$ & -0.20 & $\underline{\underline{0.94}}$ & $\underline{0.92}$ & $\underline{0.95}$ \\
\hline \multicolumn{11}{|l|}{ EVI and Rainfall } \\
\hline Spring & -0.64 & 0.40 & -0.70 & -0.39 & -0.24 & 0.53 & -0.44 & -0.32 & 0.20 & 0.41 \\
\hline Summer & -0.33 & 0.70 & 0.52 & $\underline{-0.90}$ & 0.18 & 0.33 & $\underline{0.93}$ & -0.36 & 0.60 & 0.56 \\
\hline Autumn & 0.64 & -0.32 & 0.16 & 0.14 & 0.42 & -0.15 & 0.28 & -0.06 & -0.12 & 0.26 \\
\hline Winter & 0.21 & 0.74 & 0.49 & 0.55 & 0.71 & $\underline{0.86}$ & -0.48 & 0.76 & $\underline{0.95}$ & $\underline{0.90}$ \\
\hline
\end{tabular}

See Figure 1 to identify the grassland typologies

Table 3. Averages of the phenological metrics for the grassland typologies of Rio Grande do Sul state, Brazil, for the period from 2001 to 2014

\begin{tabular}{lcccccccccc}
\hline \multicolumn{1}{c}{ Metrics } & \multicolumn{10}{c|}{ Grassland typologies } \\
\cline { 2 - 11 } & HIG & COG & SAG & AAG & GRG & VCG & ARG & SHG & SSG & ECG \\
Start of vegetative cycle (month) & $10 / 09$ & $09 / 23$ & $09 / 07$ & $09 / 19$ & $10 / 13$ & $09 / 12$ & $10 / 02$ & $09 / 02$ & $09 / 05$ & $09 / 10$ \\
End of vegetative cycle (month) & $08 / 30$ & $07 / 25$ & $07 / 08$ & $07 / 12$ & $08 / 14$ & $07 / 15$ & $08 / 15$ & $07 / 25$ & $07 / 31$ & $07 / 09$ \\
Date of max. phot. act. (month) & $03 / 20$ & $12 / 29$ & $12 / 22$ & $01 / 11$ & $02 / 26$ & $01 / 26$ & $03 / 10$ & $02 / 18$ & $02 / 14$ & $12 / 19$ \\
Duration of vegetative cycle (days) & 324 & 304 & 303 & 297 & 305 & 298 & 317 & 294 & 298 & 302 \\
Min. phot. act. (0-1) & 0.29 & 0.30 & 0.27 & 0.26 & 0.27 & 0.30 & 0.28 & 0.30 & 0.29 & 0.27 \\
Max. phot. act. (0-1) & 0.57 & 0.52 & 0.53 & 0.47 & 0.50 & 0.52 & 0.52 & 0.52 & 0.55 & 0.48 \\
Seasonal amplitude (0-1) & 0.28 & 0.22 & 0.26 & 0.21 & 0.23 & 0.22 & 0.24 & 0.22 & 0.26 & 0.21 \\
Growth rate (day/EVI) & 563 & 474 & 334 & 304 & 316 & 492 & 524 & 378 & 395 & 285 \\
Senescence rate (day/EVI) & 309 & 246 & 231 & 208 & 215 & 262 & 293 & 249 & 227 & 205 \\
Total productivity (day/EVI) & 98500 & 87890 & 86380 & 85780 & 92940 & 91620 & 93260 & 91210 & 86890 & 86040 \\
Seasonal productivity (day/EVI) & 34760 & 28730 & 28340 & 27560 & 31760 & 28850 & 32040 & 30790 & 29960 & 28230 \\
\hline
\end{tabular}

See Figure 1 to identify the grassland typologies

Max. phot. act. - Maximum photosynthetic activity; Min. phot. act. - Minimum photosynthetic activity; Enhanced Vegetation Index - EVI value varying from 0 to 1

the total levels of rainfall in general are not limiting (Figure 2B), promoting adequate growth and biomass accumulation. However, it is verified that, in the south-central portion of the state, there is variability in the date of regrowth, which may be associated with local issues related to soil, relief, species composition or management of the grasslands.

For the metric of end of phenological cycle (Figure 3B), the pattern between the typologies was similar to that previously described. Senescence occurred between the months of July and August, highly associated with the reduction in air temperature, first in the south-central regions and, with a certain delay, in the northeast and coastal areas.

The date of maximum photosynthetic activity (Figure 3C) and the duration of the cycle (Figure 3D), as a consequence, also show similar patterns of distribution in the state. Northeast and coastline differed from the others, with later date of maximum photosynthetic activity and longer duration of the cycle.

The duration of the seasonal cycle, expressed in days and corresponding to the period of development of the grasslands, from regrowth to senescence, that is, the interval between the start and end of the phenological cycle, ranged from 288 to 335 days (10 to 11 months), extending from spring to winter (Figure 3D). The duration of the cycle occurred differently, being shorter for the typologies SAG, AAG, ECG, COG, VCG, SHG and SSG and longer for the typologies HIG, ARG and GRG (Table 3).

The date of minimum photosynthetic activity (Figure 3E) occurred between the months of July and August and is directly associated with the end of the phenological cycle, marked by the senescence of the grassland vegetation and represented by the low EVI values, which ranged from 0.26 to 0.30 (base level), and predominance of species with $\mathrm{C}_{3}$ photosynthetic metabolism (Boldrini et al., 2015).

The values of maximum photosynthetic activity (Figure 3F) occurred between December (summer) and March (autumn), defining in these months the peak of vegetative development, determined by the metric of maximum photosynthetic activity, with average values of EVI ranging from 0.46 to 0.60 . In this period, there was a predominance of $\mathrm{C}_{4}$ grasses, which grow during spring and summer. Again, the south-central region of the state showed a less homogeneous pattern of growth, with nearby areas showing distinct photosynthetic activities, which was possibly associated with the water availability factor.

The association of $\mathrm{C}_{3}$ and $\mathrm{C}_{4}$ species, which succeed in time is an important characteristic of the grasslands of Rio Grande do Sul state, Brazil, and determine the growth capacity of the vegetation in the four seasons of the year, defining a certain balance of the annual forage production (Maraschin, 2009). Nevertheless, it was observed that the seasonal amplitude, determined by the difference between the maximum value of EVI and the base level, showed values between 0.21 and 0.31 (Figure 3G).

The amplitude (Figure 3G) evidences the seasonal variation of the photosynthetic activity characteristic of the grassland vegetation, with marked phenological cycle showing high values of EVI in the summer and low values in the winter. The lowest values were distributed among the typologies of ECG and AAG (Table 3), which show climatic similarity, with predominance of Orthents and Quartzipsamments, respectively, i.e., soils with low water retention capacity, a 


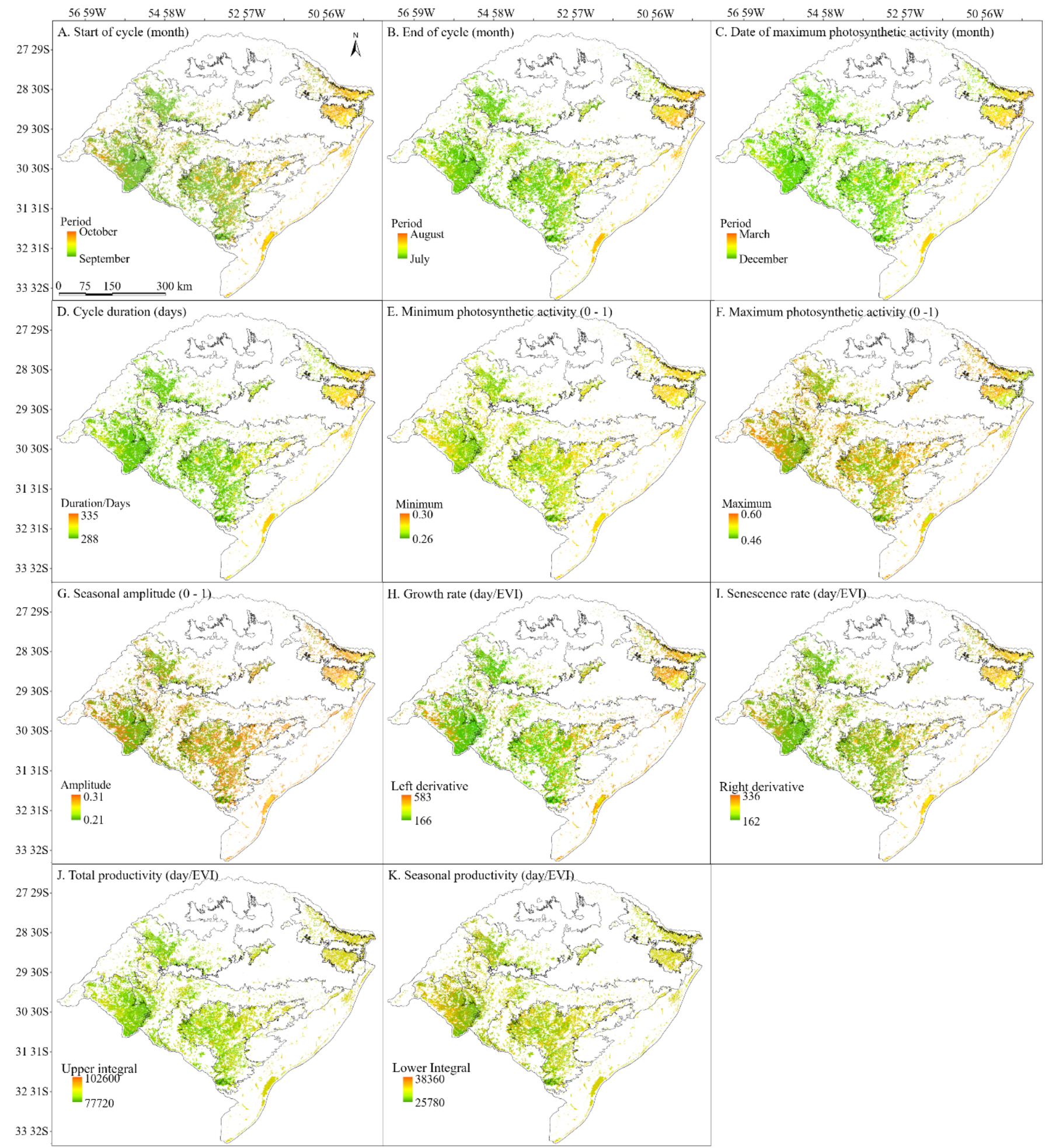

Figure 3. Phenological metrics obtained from the Enhanced Vegetation Index (EVI/MODIS) time series, period from 2001 to 2014, for the grassland vegetation of Rio Grande do Sul state, Brazil

condition that is worsened by the occurrence of drought and high temperatures, especially in the summer (Boldrini et al., 2010), leading to the lowest values of EVI.

The metrics related to growth rate (Figure $3 \mathrm{H}$ ) and senescence rate (Figure 3I), associated with the periods of regrowth and senescence of the vegetation, respectively, repeated the already described pattern of distribution between the typologies. It was found that the growth rate (166-583) was higher than the senescence rate (162-336). During the winter, the low temperatures associated with the occurrence of frost limit the growth of $\mathrm{C}_{4}$ species, which are responsible for most of the forage production in the grasslands. Depending on their intensity and duration, they compromise vegetation growth and development (Jacóbsen et al., 2003). The start of spring and the increase in the values of air temperature and solar radiation availability stimulates the flowering of $\mathrm{C}_{3}$ species and, along the summer, an increase in the number of $\mathrm{C}_{4}$ species, which also produce their inflorescences.

According to Boldrini et al. (2015), this alternation in the flowering season of the grassland vegetation completely 
changes the aspect of the landscape in one-month period. This characteristic also influences the total productivity (Upper integral) (Figure 3J) and the seasonal productivity (Lower integral) (Figure $3 \mathrm{~K}$ ) of the vegetation, which had the highest values for the typologies HIG, ARG and GRG in comparison to the typologies SAG, AAG, ECG, COG, VCG, SHG and SSG (Table 3 ). These results confirm that the climatic variability influences the distribution of the grassland species and characterizes their spatialization on a regional scale. Boldrini et al. (2010) added that the vegetation distribution is not homogeneous and depends on the survival capacity and competitive ability among the species, and their establishment is influenced by limiting conditions related to geomorphology, hydrology, pedology, climate and anthropic action.

\section{Conclusions}

1. The Enhanced Vegetation Index (EVI) time series of the MODIS sensor allowed extracting information on the phenological variables of the grassland vegetation of Rio Grande do Sul state, Brazil, in which subtropical climate conditions prevail.

2. There is a spatial distribution pattern between the phenological metrics with the grouping of the typologies Aristida spp. grasslands, sandy grassland, shallow soils grasslands, shrubby grassland, grassy grassland, Andropogonean and Asteraceae mixed grasslands, and eastern crystaline mixed grasslands, located in the south-central region and for the typologies highland grassland, coastal grassland and Vachellia caven grasslands, distributed to Northeast, along the coast and in the far west of the state, respectively.

3. The phenological pattern of the grassland vegetation is marked by the seasonality of the vegetation, which is associated with variations in air temperature and rainfall.

\section{ACKNOWLedgments}

To the Coordenação de Aperfeiçoamento de Pessoal de Nível Superior (CAPES) for granting the doctoral scholarship to the author. To Dr. Júlio Cesar Dalla Mora Esquerdo, for the assistance with the Timesat program.

\section{Literature Cited}

Balsamo, G.; Albergel, C.; Beljaars, A.; Brun, E.; Cloke, H.; Dee, D.; Dutra, E.; Munõz-Sabater, J.; Pappenberger, F.; Rosnay, P.; Stockdale, T.; Vitart, F. ERA-Interim/Land: A global land surface reanalysis data set. Hydrology and Earth System Sciences, v.19, p.389-407, 2015. https://doi.org/10.5194/hess-19-389-2015

Berlato, M. A.; Fontana, D. C. El Niño e La Niña: Impactos no clima, na vegetação e na agricultura do Rio Grande do Sul. Aplicações de previsões climáticas na agricultura. Porto Alegre: UFRGS Editora, 2003. 110p.

Berrisford, P.; Dee, D.; Poli, P.; Brugge, R.; Fielding, K.; Fuentes, M.; Kallberg, P.; Kobayashi, S.; Uppala, S.; Simmons, A. The ERAInterim archive. European Centre for Medium Range Weather Forecasts, v.1, p.1-27, 2011.
Boldrini, I. I.; Ferreira, P. M. A.; Andrade, B. O.; Schneider, A. A.; Setubal, R. B.; Trevisan, R.; Freitas, E. M. Bioma Pampa: Diversidade florística e fisionômica. Porto Alegre: Pallotti, 2010. 64p.

Boldrini, I. I.; Longhi-Wagner, H. M. Poaceae no Rio Grande do Sul: Diversidade, importância na fisionomia e conservação. Ciência \& Ambiente, v.42, p.71-92, 2011.

Boldrini, I. I.; Overbeck, G.; Trevisan, R. Biodiversidade de plantas. In: Pillar, V. P.; Lange, O. Os campos do Sul: Rede Campos Sulinos. Porto Alegre: UFRGS, 2015. Cap.5, p.51-56.

Cerqueira, E. O.; Poppi, R. J.; Kubota, L. T.; Mello, C. Utilização de filtro de transformada de Fourier para a minimização de ruídos em sinais analíticos. Química Nova, v.23, p.690-698, 2000. https:// doi.org/10.1590/S0100-40422000000500019

Gao, F.; Morisette, J. T.; Wolfe, R. E.; Ederer, G.; Pedelty, J.; Masuoka, E.; Myneni, R.; Tan, B.; Nightingale, J. An algorithm to produce temporally and spatially continuous MODIS-LAI time series. IEEE Geoscience and Remote Sensing, v.5, p.60-64, 2008. https:// doi.org/10.1109/LGRS.2007.907971

Hasenack, H.; Weber, E.; Boldrini, I. I.; Trevisan, R. Sistemas ecológicos das Savanas uruguaias. Porto Alegre: UFRGS, 2010. Available on: < https://www.ufrgs.br/labgeo/index.php/dadosespaciais/249-sistemas-ecologicos-das-savanas-uruguaias $>$. Accessed on: Out. 2016.

Hermance, J. F.; Augustine, D. J.; Derner, J. D. Quantifying characteristic growth dynamics in a semi-arid grassland ecosystem by predicting shortterm NDVI phenology from daily rainfall: A simple four parameter coupled-reservoir model. International Journal of Remote Sensing, v.36, p.5637-5663, 2015. https://doi. org/10.1080/01431161.2015.1103916

Jacóbsen, L. O.; Fontana, D. C.; Shimabukuro, Y. E. Alterações na vegetação em macrozonas do Rio Grande do Sul associados a eventos El Niño e La Niña, usando imagens NOAA. Revista Brasileira de Meteorologia, v.11, p.361-374, 2003.

Jönsson, P.; Eklundh, L. Seasonality extraction by function fitting to time-series of satellite sensor data. IEEE Transactions on Geoscience and Remote Sensing, v.40, p.1824-1832, 2002. https:// doi.org/10.1109/TGRS.2002.802519

Jönsson, P.; Eklundh, L. Timesat: A program for analyzing time-series of satellite sensor data. Computers and Geosciences, v.30, p.833845, 2004. https://doi.org/10.1016/j.cageo.2004.05.006

Junges, A. H.; Bremm, C.; Fontana, D. C.; Oliveira, C. A. O.; Schaparini, L. P.; Carvalho, P. C. F. Temporal profiles of vegetation indices for characterizing grazing intensity on natural grasslands in Pampa biome. Scientia Agricola, v.73, p.332-337, 2016. https:// doi.org/10.1590/0103-9016-2015-0213

Lieth, H. Purposes of a phenology book. In: Lieth, H. Phenology and seasonality modeling. New York: Springer-Verlag, 1974. Cap.1, p.3-19. https://doi.org/10.1007/978-3-642-51863-8_1

Maraschin, G. E. Manejo do campo nativo, produtividade animal, dinâmica da vegetação e adubação de pastagens nativas do sul do Brasil. In: Pillar, V. P. Campos sulinos: Conservação e uso sustentável da biodiversidade. Brasília: MMA, 2009. Cap.19, p.248-259.

Paruelo, J. M. La caracterización funcional de ecosistemas mediante sensores remotos. Ecossistemas, v.17, p.4-22, 2008.

Prabakaran, C.; Singh, C. P.; Panigrahy, S.; Parihar, J. S. Retrieval of forest phenological parameters from remote sensing-based NDVI time-series data. Current Science, v.105, p.795-802, 2013.

Scottá, F. C.; Fonseca, E. L. Multiscale trend analysis for Pampa grasslands using ground data and vegetation sensor imagery. Sensors, v.15, p.17666-17692, 2015. https://doi.org/10.3390/s150717666 
Soudani, K.; Hmimina, G.; Delpierre, N.; Pontailler, J. Y.; Aubinet, M.; Bonal, D.; Caquet, B.; Grandcourt, A. de; Burban, B.; Flechard, C.; Guyon, D.; Granier, A.; Gross, P.; Heinesh, B.; Longdoz, B.; Loustau, D.; Moureaux, C.; Ourcival, J. M.; Rambal, S.; Saint André, L.; Dufrêne, E. Ground-based network of NDVI measurements for tracking temporal dynamics of canopy structure and vegetation phenology in different biomes. Remote Sensing of Environment, v.123, p.234-245, 2012. https://doi.org/10.1016/j.rse.2012.03.012 Tan, B.; Morisette, J. T.; Wolfe, R. E.; Gao, F.; Ederer, G. A.; Nightingale, J.; Pedelty, J. A. An enhanced TIMESAT algorithm for estimating vegetation phenology metrics from MODIS data. IEEE Journal of Selected Topics in Applied Earth Observations and Remote Sensing, v.4, p.361-371, 2011. https://doi.org/10.1109/JSTARS.2010.2075916

Teles, T. S.; Galvão, L. S.; Breuning, F. M.; Balbinot, R.; Gaida, W. Relationships between MODIS phenological metrics, topographic shade, and anomalous temperature patterns in seasonal deciduous forests of south Brazil. International Journal of Remote Sensing, v.36, p.4501-4518, 2015. https://doi.org/10.1080/01431161.2015.1084437
Tiedemann, J. L. Fenología del bosque de las subregiones neturales: Chaco, Semiárido y Chaco Serrano, de Santiago del Estero, Argentina. Ecología Aplicada, v.10, p.51-59, 2011. https:/doi. org/10.21704/rea.v10i1-2.413

Wagner, A. P. L.; Fontana, D. C.; Fraisse, C.; Weber, E. J.; Hasenack, H. Tendências temporais de índices de vegetação nos campos do Pampa do Brasil e do Uruguai. Pesquisa Agropecuária Brasileira, v.48, p.1192-1200, 2013. https://doi.org/10.1590/S0100204X2013000900002

Weber, E. J.; Hoffmann, G. S.; Oliveira, C. V.; Hasenack, H. Uso e cobertura vegetal do estado do Rio Grande do Sul: Situação em 2009. Porto Alegre: UFRGS, 2009. Available on: <https://www. ufrgs.br/labgeo/>. Accessed on: Jan. 2017.

Zhang, X.; Friedl, M. A.; Schaaf, C. B. Global vegetation phenology from Moderate Resolution Imaging Spectroradiometer (MODIS): Evaluation of global patterns and comparison with in situ measurements. Journal of Geophysical Research, v.111, p.1-14, 2006. https://doi.org/10.1029/2006JG000217 